\title{
DECOLORIZATION OF DIFFERENT TEXTILE DYES BY PENICILLIUM SIMPLICISSIMUM AND TOXICITY EVALUATION AFTER FUNGAL TREATMENT
}

\author{
Bergsten-Torralba, L.R. ${ }^{1}$; Nishikawa, M.M. ${ }^{1}$ Baptista, D.F. ${ }^{2}$; Magalhães, D.P. ${ }^{2}$; da Silva, M. ${ }^{{ }^{*}}$ \\ ${ }^{1}$ Programa de Pós-Graduação em Vigilância Sanitária, Instituto Nacional de Controle de Qualidade em Saúde, Fundação \\ Oswaldo Cruz, Rio de Janeiro, RJ, Brasil; ${ }^{2}$ Laboratório de Avaliação e Promoção da Saúde Ambiental, Instituto Oswaldo Cruz, \\ Fundação Oswaldo Cruz, Rio de Janeiro, RJ, Brasil.
}

Submitted: January 27, 2009; Returned to authors for corrections: March 26, 2009; Approved: May 15, 2009.

\begin{abstract}
The objective of this study was to investigate the capacity of decolorization and detoxification of the textile dyes Reactive Red 198 (RR198), Reactive Blue 214 (RB214), Reactive Blue 21 (RB21) and the mixture of the three dyes (MXD) by Penicillium simplicissimum INCQS 40211. The dye RB21, a phthalocyanine, was totally decolorized in 2 days, and the others, the monoazo RR198, the diazo RB214 and MXD were decolorized after 7 days by P. simplicissimum. Initially the dye decolorization involved dye adsorption by the biomass followed by degradation. The acute toxicity after fungal treatment was monitored with the microcrustacean Daphnia pulex and measured through Effective Concentration 50\% $\left(\mathrm{EC}_{50}\right)$. P. simplicissimum reduced efficiently the toxicity of RB21 from moderately acutely toxic to minor acutely toxic and it also reduced the toxicity of RB214 and MXD, which remained minor acutely toxic. Nevertheless, the fungus increased the toxicity of RR198 despite of the reduction of MXD toxicity, which included this dye. Thus, $P$. simplicissimum INCQS 40211 was efficient to decolorize different textile dyes and the mixture of them with a significant reduction of their toxicity. In addition this investigation also demonstrated the need of toxicological assays associated to decolorization experiments.
\end{abstract}

Key words: fungi, textile dyes, decolorization, detoxification.

\section{INTRODUCTION}

Textile industry is a very important segment in the Brazilian economy, with considerable growth in the last years. As a consequence, there is an increase of environmental contamination caused by the large amount of dyes involved in the textile process that are discharged in the liquid effluents. Approximately $10-15 \%$ of the dyes are released into the environment (38).
Azo dyes are the main chemical class of dyes with the greatest variety of colors, therefore they have been extensively used by the industry. These dyes are characterized by one or more azo linkages $\left(\mathrm{R}_{1}-\mathrm{N}=\mathrm{N}-\mathrm{R}_{2}\right)$ and by aromatic structures $(22,40)$. The biological effects of azo dyes after biotransformation have been shown to be toxic (34), and in some cases these compounds are carcinogenic and mutagenic $(14,29)$. 
There are many effective wastewater treatments; however these technologies are highly expensive. Biological treatments that have been conventionally applied present certain drawbacks. Some textile dyes are relatively resistant to microbial degradation, besides that anaerobic microorganisms when degrading some dyes produce aromatic amines that may be toxic and carcinogenic (47). Therefore, in recent years, there have been intensive researches on fungal decolorization of textile wastewater. The use of fungi is a promising alternative to replace or supplement current treatments $(8,13,18)$.

Several fungi are capable of mineralizing pollutant compounds through their highly oxidative and non-specific ligninolytic enzymes, which are also responsible for the decolorization and degradation of many different dyes (13). The white rot fungi, members of the Basidiomycetes, as Funalia trogii (47), Phanerochaete chrysosporium (3, 27), Trametes versicolor (34), Trametes hirsuta (1), Irpex lacteus (Novotný et al, 2004) and Lentinula edodes (5, 21) are extremely efficient for textile dye degradation.

Studies on non-basidiomycete fungi that degrade dyes are reduced; nevertheless these fungi are also very efficient for metabolizing a wide range of compounds, particularly by demethylation and oxidation (6). Aspergillus species (14, 24, 36), Cunninghamella elegans (2), Penicillium geastrivorus (46), P. ochrochloron (37), Pestalotiopsis guepinii (35) and Umbelopsis isabellina (46) were found to be successful for removing textile dyes from liquid media.

Despite of the efficiency of biological treatments, in some cases microorganisms can transform dyes into compounds more toxic than the original compound,
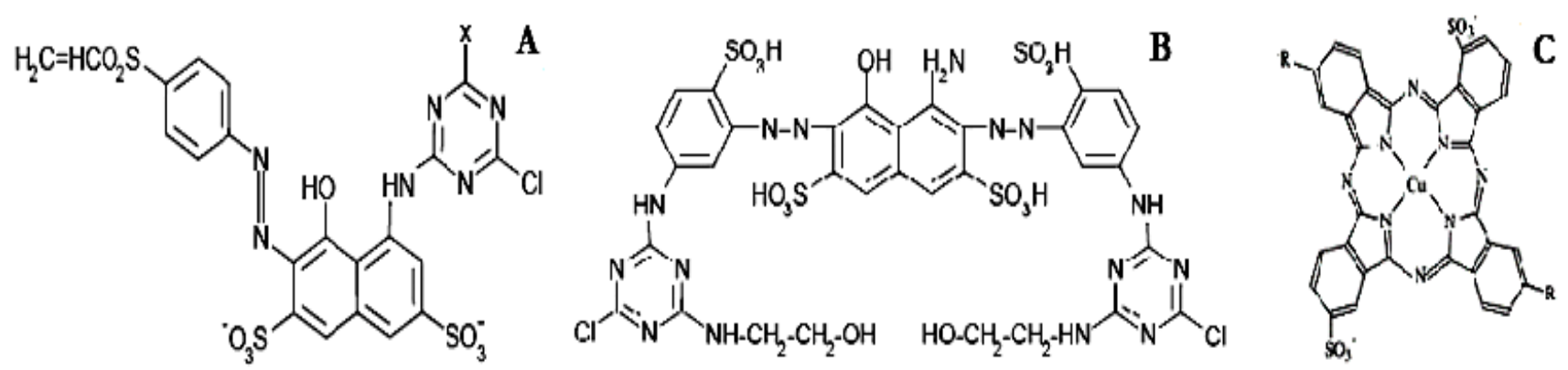

Figure 1. Chemical structures of the monoazo Reactive Red 198 (A), diazo Reactive Blue 214 (B) and phtalocyanine Reactive Blue 21 (C). 


\section{Microorganism}

The fungus used in this work, Penicillium simplicissimum INCQS 40211 (CCT 6686), was previously isolated from sediment collected from Rio Piaçaguera $\left(23^{\circ} 52^{\prime} 22.6^{\prime \prime} \mathrm{S}, 4^{\circ} 23^{\prime} 34.6^{\prime \prime} \mathrm{W}\right)$ in São Paulo State, Brazil, an area of estuarine habitat, under the influence of different sources of industrial contamination, including organochlorine pesticides, polychlorinated biphenyls (PCBs), furans and dioxins, organic halogens and polycyclic aromatic hydrocarbons (PAHs) (11). Among several fungi tested regarding their tolerance to pyrene, $P$. simplicissimum INCQS 40211 (CCT 6686) was the only isolate that had a better growth in the presence of pyrene than in its absence and demonstrated the highest tolerance to pyrene (11). In a further study the same fungus degraded pyrene and produced a metabolite as the result of pyrene degradation (10). Besides these studies, another investigation demonstrated the capacity of a different strain of $P$. simplicissimum to degrade polyethylene (45). Therefore, based on these abilities to degrade different compounds $P$. simplicissimum was selected for the following experiments.

Penicillium simplicissimum INCQS 40211 is deposited in the Culture Collection of INCQS/FIOCRUZ, Rio de Janeiro (RJ), Brazil. The culture has been maintained on malt extract agar and czapek yeast agar at $4^{\circ} \mathrm{C}$ and criopreserved.

\section{Culture conditions}

The fungus was inoculated into potato dextrose agar (PDA) containing the dyes separately in a final concentration of $200 \mathrm{mg} \mathrm{L}^{-1}$ and the three dyes mixed at a final concentration of $66.6 \mathrm{mg} \mathrm{L}^{-1}$ for each dye. The agar plates after inoculation were incubated at $28^{\circ} \mathrm{C}$. Following incubation for 5 days 9 mycelial plugs ( $5 \mathrm{~mm}$ diameter) from the colony margin were used as inoculums, they were transferred to conical flasks containing $150 \mathrm{~mL}$ of potato dextrose broth (PDB). Following 2-day incubation at $28^{\circ} \mathrm{C}$ on a rotary shaker at $140 \mathrm{rpm}, 100 \mathrm{mg} \mathrm{L}^{-1}$ of each dye was added $(23,28)$ and the mixture containing $33.3 \mathrm{mg} \mathrm{L}^{-1}$ of each dye was also added. Control experiments were performed under the same conditions described above but without fungi.

\section{Decolorization}

Aliquots of the fungal culture after $0,2,5,7$ and 14-day incubation following the addition of the dyes were centrifuged at $10.000 \mathrm{~g}$ for $10 \mathrm{~min}$, and then the supernatant was diluted 1:10 with distilled water and were measured spectrophotometrically using a Shimadzu UV-1601 (Kyoto, Japan) spectrophotometer. For RR198 the absorbance was observed at $520 \mathrm{~nm}$, for RB21 it was at $675 \mathrm{~nm}$, for RB214 it was at $610 \mathrm{~nm}$ and for the mixture of the three dyes (MXD) it was at $620 \mathrm{~nm}$. The color removal was reported as percentage decolorization $(\%)=\left(A_{b}-A_{a}\right) / A_{b} \times 100$, where $A_{b}$ is the absorbance of the initial dye solution (day 0) and $A_{a}$ is the absorbance at cultivation time (2, 5, 7 and 14 days) (32). All assays were conducted in triplicate in the dark and results were expressed as the mean values with the standard deviation calculated.

\section{Ecotoxicity}

The freshwater microcrustacean Daphnia pulex was used for the acute toxicity determination and the methodology applied was based on OECD 202 protocol (31). D. pulex was cultured in mineral water (Minalba $\left.{ }^{\circledR}\right)$ in a temperaturecontrolled chamber at $23 \pm 1{ }^{\circ} \mathrm{C}$, with a light intensity of 40 $\mu \mathrm{E} \mathrm{m}^{-2} \mathrm{~s}^{-1}$ and a 12:12 $\mathrm{h}$ light:dark cycle. The daphnids were fed with the chlorophyte Ankistrodesmus falcatus (strain NPIN-1) that was cultured in MBL medium (39).

The toxicity determination was conducted with the liquid media containing the dyes before and after the 14-day incubation with $P$. simplicissimum. The liquid media was filtered through polyethersulfone membrane $0,22 \mu \mathrm{m}$ and the supernatant was evaluated. The method applied was static using 20 neonates divided in two groups of 10 individuals for concentration-test. The mineral water was used as dilution water for the concentration-test and as control. The time of exposition was 24 hours under constant temperature of $24^{\circ} \mathrm{C}$ and in the dark. 
The supernatants were tested in a concentration series $(0.2,0.4,0.8,1.6,3.1,6.2,12.5,25,50,75,100 \%)$ in order to obtain the $24 \mathrm{~h}$ exposition average Effective Concentration $\left(24 \mathrm{~h}-\mathrm{EC}_{50}\right)$, which is the concentration where $50 \%$ of the daphnids were affected (mortality or immobility), and was estimated by Trimmed Spearman Karber regression analysis (19). The $\mathrm{EC}_{50}$ obtained were classified according to Verma (43).

\section{RESULTS AND DISCUSSION}

\section{Decolorization}

The standard deviation of the triplicates of each dye and the dye mixture was calculated for the five periods of decolorization analyses ( $0,2,5,7$ and 14 days of incubation) and the deviation was not higher than $0.02 \%$ (data not shown). Therefore, the results were reproducible for the three dyes tested and their mixture.
P. simplicissimum INCQS 40211 decolorized completely $(100 \%)$ RR198 dye in liquid media after 7-day incubation (Fig. 2). The dye was adsorbed by the biomass; nevertheless, it was possible to observe visually a reduction of the dye adsorption from the $5^{\text {th }}$ to the $7^{\text {th }}$ day of incubation (Fig. 3).

In the presence of RB21 the liquid media was $100 \%$ decolorized by $P$. simplicissimum INCQS 40211 within 2 days of incubation (Fig. 2) and it was observed the biomass adsorbing the blue dye. The color on the biomass was reduced gradually from the $5^{\text {th }}$ until the $14^{\text {th }}$ day of incubation when the biomass was completely free from the dye (Fig. 3). Phanerochaete chrysosporium, the most studied fungus regarding degradation of a wide range of pollutant compounds, was tested in the presence of the same dye RB21 in a concentration two times higher; yet it decolorized completely the dye after 7 days. In the same investigation it was also noted that copper from the dye was adsorbed by the fungal biomass during the initial stages of dye decolorization (8).

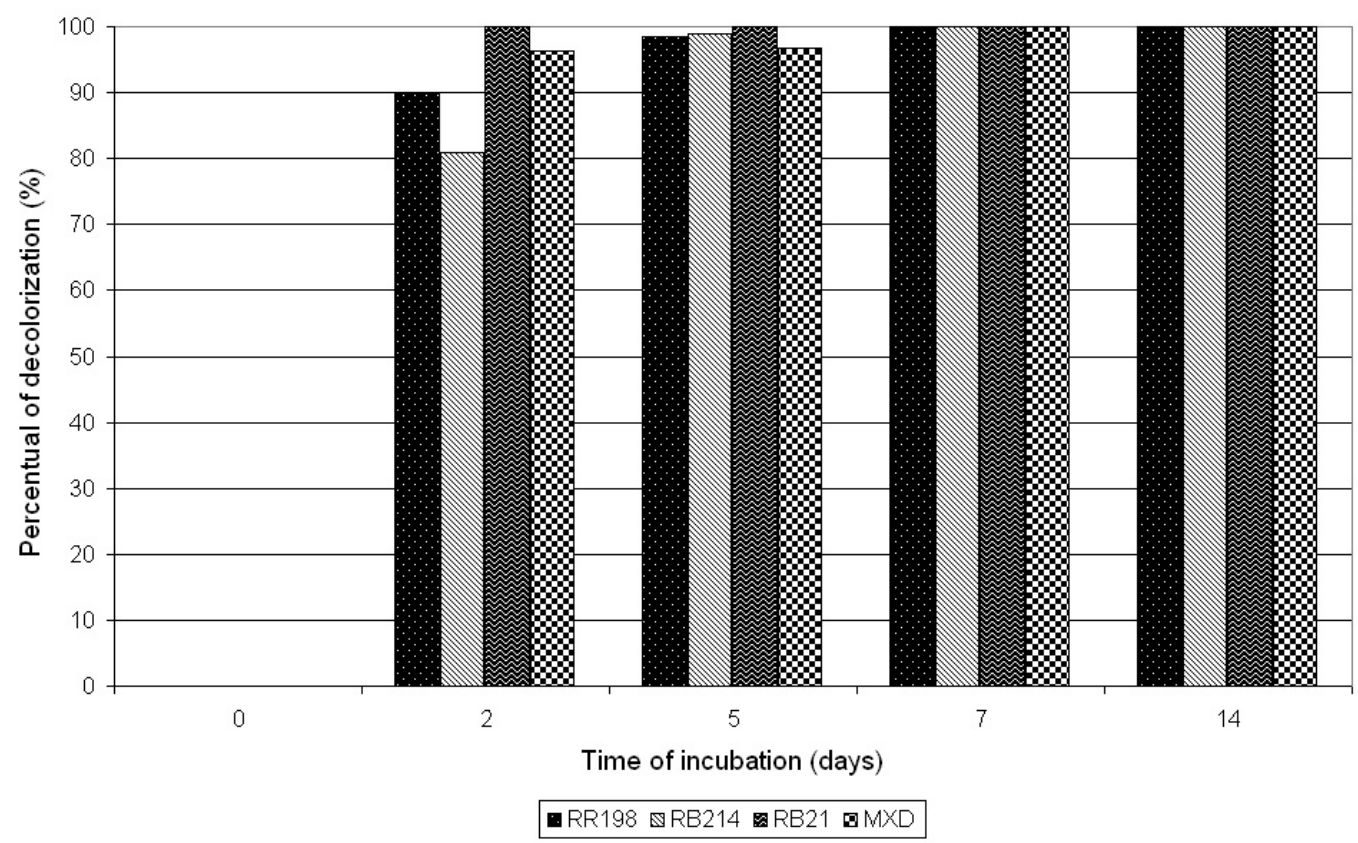

Figure 2. Decolorization of the dyes Reactive Red 198, Reactive Blue 214, Reactive Blue 21 and mixture MXD by $P$. simplicissimum INCQS 40211 after 0 day, 2 days, 5 days, 7 days and 14 days of incubation. 


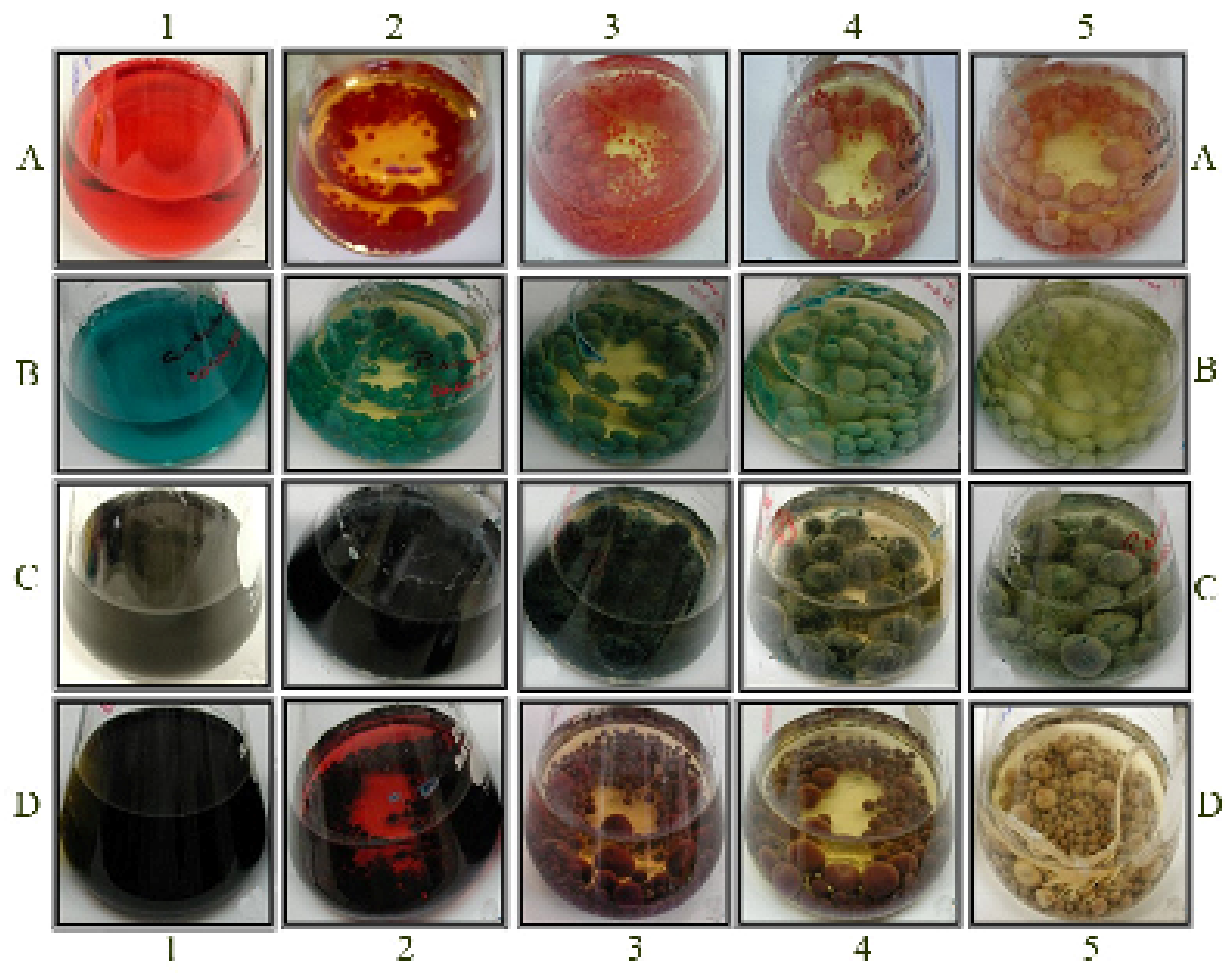

Figure 3. Visual observation of the dyes Reactive Red 198 (A), Reactive Blue 21 (B), Reactive Blue 214 (C) and mixture MXD (D) decolorized by P. simplicissimum INCQS 40211 after 0 day (1), 2 days (2), 5 days (3), 7 days (4) and 14 days (5) of incubation.

The copper in the molecular structure of the dye RB21 may influence the ability of decolorization by some fungi as formerly observed by Novotný et al. (30) regarding another dye containing copper. In another study with the same dye it was found that the dye was resistant to decolorization by cultures of methanogenic bacteria (15). P. simplicissimum INCQS 40211 compared to those other microorganisms showed more efficiency for treating this kind of dye.

The third dye tested, RB214, was 100\% decolorized after 7 days by $P$. simplicissimum INCQS 40211, however the reduction of the color from the biomass was slower than the observed with the two other dyes, RR198 and RB21 (Fig. 2 and 3), possibly due to its more complex molecular structure (Fig. 1).
When the fungus was cultivated in the presence of the mixture of the three dyes, MXD, it decolorized $100 \%$ of the culture supernatant after 5 days (Fig. 2) when the biomass visually had adsorbed most of the dyes. From the $5^{\text {th }}$ day till the $14^{\text {th }}$ day of incubation there was a gradual reduction of the color on the biomass until complete disappearance (Fig. $3)$.

During the present experiment it was demonstrated the efficiency of $P$. simplicissimum INCQS 40211 to decolorize the three different kinds of dyes, a monoazo (RR198), a diazo (RB214) and a phthalocyanine (RB21), with differences in the decolorization ability regarding each dye tested, which might be dependent on dye structure (18). Relatively small structural differences can markedly affect decolorization (25). 
Yet the relationship between the molecular structure of the dyes and their decolorization by fungi is still unclear.

The decolorization of the liquid media was confirmed by the disappearance of the characteristic peak of these dyes during the spectrophotometric experiments (Fig. 4). In the meantime the dyes were adsorbed by the biomass and from visual observation they gradually disappeared from its surface. Visual observation of the biomass is an important
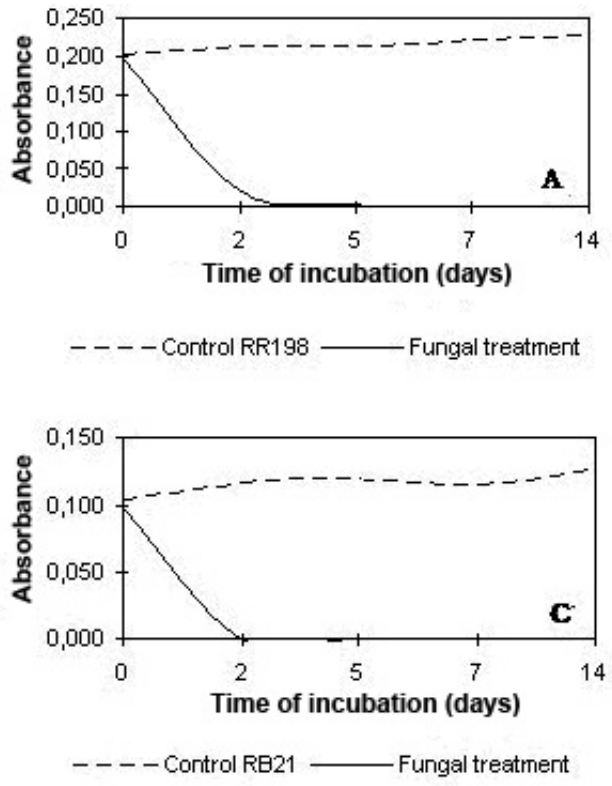

aspect in dye decolorization investigation, since it allows the distinction of biomass adsorption from microbial degradation $(7,48)$. Therefore, the reduction of color on the biomass observed in Figure 3 with the three dyes and the dye mixture indicates a potential dye degradation by $P$. simplicissimum INCQS 40211.
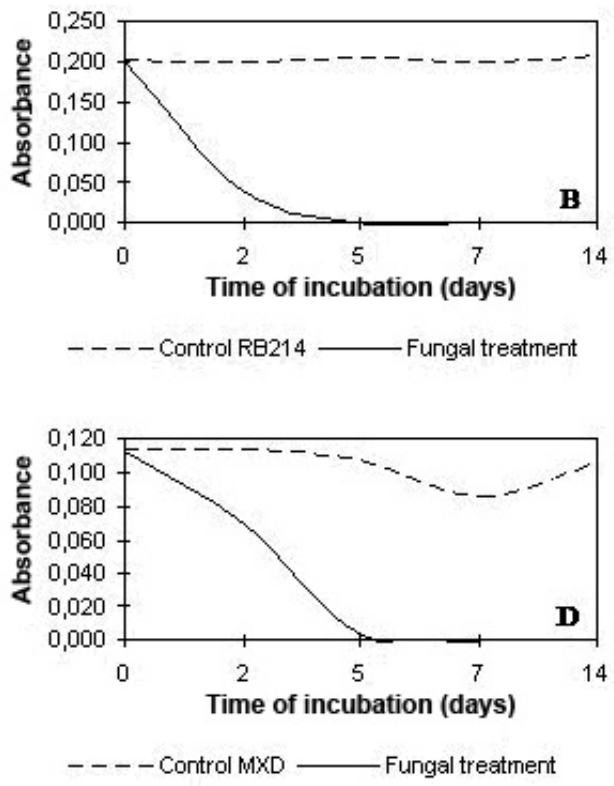

Figure 4. Absorbance (abs) of the characteristic peak ( $\lambda_{\max }$ of the dye) each of dye before and after treatment by $\mathrm{P}$. simplicissimum INCQS 40211 after 14 days of incubation. A - abs of RR198; B - abs of RB21; C - abs of RB214 and D - abs of the mixture MXD.

A study conducted by Zheng et al. (50) showed that Penicillium sp. removed the dyes Poly R-478 and Poly S-119 by adsorption and subsequently degraded them. Works on dye decolorization by $P$. simplicissimum were not found in the literature, this is the first report, yet there are studies on enzymatic activities by this fungus. Zeng et al. (49) observed the production of laccase and that the activity of this enzyme increased significantly after the exhaustion of simple carbon source, cellulose, and the use of a more complex carbon source, lignin. Other investigations showed the production of intracellular enzymes by $P$. simplicissimum, such as vanillyl- alcohol oxidase and catalase-peroxidase, which are responsible for metabolizing a variety of compounds $(16,17)$.

Based on these findings it might be possible that the biomass decolorization, promoted by $P$. simplicissimum INCQS 40211 from the $5^{\text {th }}$ to the $14^{\text {th }}$ day of incubation, was initiated after the consumption of the simple carbon source, glucose, leading the fungus to use the dyes as the source of complex carbon through intra or extracellular enzymes. It would be necessary further investigations on enzyme activities involved in the dye degradation by this fungus. 


\section{Ecotoxicity}

The effluents from textile industries even after the treatment can remain toxic and mutagenic; nonetheless they are released into the environment any way. Consequently, the inefficiency of this process leads to the need of toxicological assays after effluent treatment $(12,26,42)$. Thus, in the present investigation the toxicological tests were performed using daphnids since they have been found to be sensitive (41) and used as important models to evaluate the toxicological implications that may result from azo dyes to the environment $(4,44)$.

The $24 \mathrm{~h}-\mathrm{EC}_{50}$, obtained with the acute toxicity test using Daphnia pulex, of the liquid media before and after the fungal treatment with $P$. simplicissimum INCQS 40211 was determined (Table 1). The dyes RR198, RB214 and MXD before the treatment were minor acutely toxic $\left(\mathrm{EC}_{50}=10\right.$ $100 \%$ ) while the dye RB21 was moderately acutely toxic $\left(\mathrm{EC}_{50}=1-10 \%\right)$. The toxicity observed for this phthalocyanine dye is probably due to the presence of cooper in its chemical structure (Fig. 1). This toxicity has already been observed by Novótny et al. (30) when testing another dye containing copper, which inhibited fungal growth. Despite of MXD being constituted also by the toxic dye RB21, the low toxicity of the mixture is probably due to fact that RB21 was in a low concentration $\left(33.3 \mathrm{mg} \mathrm{L}^{-1}\right)$, as was also concluded by $\mathrm{Fu} \&$ Viraraghavan (18). After the fungal treatment, $P$. simplicissimum INCQS 40211 efficiently reduced the toxicity of this dye, the $24 \mathrm{~h}-\mathrm{EC}_{50}$ value was increased from $1.1 \%$ (moderately acutely toxic) to $20.3 \%$ (minor acutely toxic) (Table 1).

Table 1. Results of ecotoxicological assay with microcrustacean Daphnia pulex of RR198, RB214, RB21 and MXD before and after fungal treatment with $P$. simplicissimum at the end of 14 days of incubation.

\begin{tabular}{lccc}
\hline Samples & EC50 \% & CI 95\% & Classification \\
\hline RR198 & 30.8 & $27.2-34.8$ & Minor acutely toxic \\
$P$. simplicissimum in RR198 & 9.5 & $8.6-10.4$ & Moderately acutely toxic \\
RB214 & 31.4 & $26.4-37.4$ & Minor acutely toxic \\
$P$. simplicissimum in RB214 & 34.8 & $28.8-42.1$ & Minor acutely toxic \\
RB21 & 1.1 & NR & Moderately acutely toxic \\
$P$. simplicissimum in RB21 & 20.3 & $17.9-23.0$ & Minor acutely toxic \\
Mixture MXD & 42.2 & $30.4-58.5$ & Minor acutely toxic \\
$P$. simplicissimum in MXD & 49.8 & $41.4-59.9$ & Minor acutely toxic
\end{tabular}

Note: $\mathrm{EC}_{50}-$ Effective Concentration; $\mathrm{EC}_{50}<1-$ Acutely toxic; $\mathrm{EC}_{50}=1-10 \%$ - Moderately acutely toxic; $\mathrm{EC}_{50}=10-100 \%-\mathrm{Minor}_{0}$ acutely toxic; $\mathrm{EC}_{50}>100 \%$ - Not acutely toxic.

CI 95\% - $95 \%$ Confidence Intervals.

NR - not reliable.

The fungus also reduced the toxicity of the dye RB214 and the dye mixture, MXD. The $\mathrm{EC}_{50}$ values of RB214 and MXD, were increased from $31.4 \%$ to $34.8 \%$ and from $42.1 \%$ to $49.8 \%$, respectively, remaining minor acutely toxic
$\left(\mathrm{EC}_{50}=10-100 \%\right)$ (Table 1). Yet the contrary was observed with the dye RR198, after fungal treatment its toxicity increased from minor acutely toxic to moderately acutely toxic (Table 1). The toxicity increase could be explained by 
the presence of metabolites produced by $P$. simplicissimum INCQS 40211 after decolorization, which was more toxic than the dye RR198, as it was formerly observed by Ramsay \& Nguyen (34) with another dye. Despite of this toxicity increase, when RR198 was treated in the presence of the other two dyes (MXD), the toxicity was reduced by $P$. simplicissimum INCQS 40211. Possibly in this case the toxic effect of the metabolite produced by the fungus was suppressed. Since the dyes are not present in the environment isolated but in a mixture, the positive result obtained with MXD is more important than the negative result with RR198.

The toxicological assay using daphnids showed a significant reduction of toxicity after dye decolorization $P$. simplicissimum INCQS 40211, indicating that this process corresponds to an actual detoxification of the dyes. Even though the detoxification in some treatments is not always reduced while the decolorization takes place, as it happened in the present study with the dye RR198, there are very few studies that have evaluated the toxicological level after dye or effluent treatment $(26,33,41)$. Therefore, based on these findings, the need of this kind of evaluation has been confirmed.

\section{CONCLUSION}

Penicillium simplicissimum INCQS 40211 was efficient to decolorize different kinds of dyes and the mixture of them by initially adsorbing them and subsequently degrading them, which led to the decolorization of the biomass. This fungus was also capable to detoxify 2 dyes and the mixture of the three dyes tested. More studies regarding dye degradation and toxicity reduction by $P$. simplicissimum INCQS 40211 are necessary. Yet, most importantly the results of this investigation demonstrated the great significance of toxicological assays associated with decolorization experiments.
The present work was supported by a master scholarship from Fiotec/Fiocruz and a grant from CNPq (UNIVERSAL, 484977/2007-5). The authors are indebted to Dystar industry (SP, Brazil) and Instituto Nacional de Tecnologia (RJ, Brazil) for donating the dyes used in the present investigation.

\section{REFERENCES}

1. Abadulla, E.; Tzanov, T.; Costa, S.; Robra, K.H.; Cavaco-Paulo, A.; Gübitz, G.M. (2000). Decolorization and detoxification of textile dyes with a laccase from Trametes hirsuta. Appl. Environ. Microbiol. 66, 3357-3362.

2. Ambrósio, S.T.; Campos-Takaki, G.M. (2004). Decolorization of reactive azo dyes by Cunninghamella elegans UCP 542 under cometabolic conditions. Biores. Technol. 91, 69-75.

3. Arora, D.S.; Chander, M. (2004). Decolourisation of diverse industria dyes by some Phlebia spp. and their comparison with Phanerochaete chrysosporium. J. Basic. Mycrobiol. 44, 331-338.

4. Bae, J.S.; Freeman, H.S. (2002). Synthesis and evaluation of nongenotoxic direct dyes. Fibers Polym. 3, 140-146.

5. Boer, C.G.; Obici, L.; Souza, C.G.M.; Peralta, R.M. (2004). Decolorization of synthetic dyes by solid state cultures of Lentinula (Lentinus) edodes producing manganese peroxidase as the main ligninolytic enzyme. Biores. Technol. 94, 107-112.

6. Cha, C.J.; Doerge, D.R.; Cerniglia, C.E. (2001). Biotransformation of malachite green by the fungus Cunninghamella elegans. Appl. Environ. Microbiol. 67, 4358-4360.

7. Chen, K.C.; Wu, J.Y.; Liou, D.J.; Hwang, S.C.J. (2003). Decolorization of the textile dyes by newly isolated bacterial strains. J. Biotechnol. $101,57-68$

8. Conneely, A.; Smyth, W.F.; McMullan, G. (1999). Metabolism of the phthlocyanine textile dye remazol turquoise blue by Phanerochaete chrysosporium. FEMS Microbiol. Lett. 179, 333-337.

9. Coulibaly, L.; Gourene, G.; Spiros, A.N. (2003). Utilization of fungi for biotreatment of raw wastewaters. Afri. J. Biotechnol. 2, 620-630.

10. da Silva, M.; Cerniglia, C.E.; Pothuluri, J.V.; Canhos, V.P.; Esposito, E. (2003b). Screening filamentous fungi isolated from estuarine sediments for the ability to oxidize PAHs. World J. Microbiol. \& Biotechnol. 19, $399-405$.

11. da Silva, M.; Umbuzeiro, G.A.; Pfenning, L.H.; Canhos, V.P.; Esposito, E. (2003a). Filamentous fungi isolated from estuarine sediment contaminated with industrial discharges. Soil Sedim. Contam. 12, $345-$ 356.

12. de Lima, R.O.A.; Bazo, A.P.; Salvadori, D.M.F.; Rech, C.M.; Olieveira, D.P.; Umbuzeiro, G.A. (2007). Mutagenic and carcinogenic potential of a textile azo dye processing plant effluent that impacts a drinking water resource. Mutat. Res. 626, 53-60. 
13. Dos Santos, A.Z.; Neto, J.M.C.; Tavares, C.R.G.; da Costa, M.G. (2004). Screening of filamentous fungi for the decolorization of a commercial reactive dye. J. Basic Microbiol. 44, 288-295.

14. El-Rahim, W.M.A.; Moawad, H. (2003). Enhancing bioremoval of textile dyes by eight fungal strains from media supplemented with gelatine wastes and sucrose. J. Basic Microbiol. 43, 367-375.

15. Fontenot, E.J.; Lee, Y.H.; Matthews, R.D.; Zhu, G. Pavlostathis, S.G. (2003). Reductive decolorization of textile reactive dyebath under methanogenic conditions. Appl. Biochem. Biotechnol. 109, 207-224.

16. Fraaije, M.W.; Mattevi, A.; Berkel, W.J.H.V. (1997). Mercuration of vanillil-alcohol oxidase from Penicillium simplicissimum generates inactive dimmers. FEBS Lett. 402, 33-35.

17. Fraaije, M.W.; Roubroeks, H.P.; Hagen, W.R.; van Berkel, W.J.H. (1996). Purification and characterization of an intracellular catalaseperoxidase. Eur. J. Biochem. 235, 192-198.

18. Fu, Y.; Viraraghavan, T. (2001). Fungal decolorization of dye wastewaters: a review. Biores. Technol. 79, 251-262.

19. Hamilton, M.; Russo, R.C.; Thurston, R.V. (1977). Trimmed Spearman-Karber Method for estimating median lethal concentrations in toxicity bioassays. Environ. Sci. Technol. 11 (7), 714-719.

20. Hanazato, T.; Yasuno, M. (1989). Zooplankton community structure driven by vertebrate and invertebrate predators. Oecologia $81,450-458$.

21. Hatvani, N.; Mécs, I. (2003). Effects of certain heavy metals on the growth, dye decolorization, and enzyme activity of Lentinula edodes. Ecotoxicol. Environ. Safe. 55, 199-203.

22. He, F.; Hu, W.R.; Li, Y. (2004). Biodegradation mechanisms and kinetics of azo dye 4BS by a microbial consortium. Chemosphere 57, 293-301.

23. Heinfling-Weidtmann, A.; Reemtsma, T.; Storm, T.; Szewzyk, U. (2001). Sulfophthalimide as major metabolite formed from sulfonated phthalocyanine dyes by the white-rot fungus Bjerkandera adusta. FEMS Microbiol. Lett. 203, 179-183.

24. Jin, X.C.; Liu, G.Q.; Xu, Z.H.; Tao, W.Y. (2007). Decolorization of a dye industry effluent by Aspergillus fumigatus XC6. Appl. Microbiolo. Biotechnol. 74, 239-243.

25. Knapp, J.S.; Newby, P.S.; Reece, L.P. (1995). Decolorization of dyes by wood-rotting basidiomycete fungi. Enzyme Microb. Technol. 17, 664-668.

26. Malachová, K.; Pavlícková, Z.; Novótny, C.; Svobodová, K.; Lednická, D.; Musílková, E. (2006). Reduction in the mutagenicity of synthetic dyes by successive treatment with activated sludge and the ligninolytic fungus, Irpex lacteus. Environ. Mol. Mutagen. 47, 533-540.

27. Martins, M.A.M.; Queiroz, M.J.; Silvestre, A.J.D.; Lima, N. (2002). Relationship of chemical structures of textile dyes on the pre-adaptation medium and the potentialities of their biodegradation by Phanerochaete chrysosporium. Res. Microbiol. 153, 361-368.
28. Máximo, C.; Amorim, M.T.P.; Costa-Ferreira, M. (2003). Biotransformation of industrial reactive azo dyes by Geotrichum sp. CCMI 1019. Enzime Microb. Technol. 32, 145-151.

29. Novótny, C.; Dias, N.; Kapanen, A.; Malachová, K.; Vándrovcová, M. Itävaara, M.; Lima, N. (2006). Comparative use of bacterial, algal and protozoan tests to study toxicity of azo and anthraquinone dyes. Chemosphere 63, 1436-1442.

30. Novótny, C.; Svobodová, K.; Kasinath, A.; Erbanová, P. (2004). Biodegradation of synthetic dyes by Irpex lacteus under various growth conditions. Int. Biodet. Biodegrad. 54, 215-223.

31. OECD - Organization for Economic Co-Oeperation and Development. (2000). Revised Proposal for updating Guideline 202. Daphnia sp. Acute Imobilisation Test.

32. Özsoy, H.D.; Ünyayar, A.; Mazmanci, M.A. (2005). Decolourisation of reactive textile dyes Drimarene Blue X3LR and Remazol Brilhant Blue R by Funalia trogii ATCC 200800. Biodegradation 16, 195-204.

33. Prigione, V.; Tigini, V.; Pezzella, C.; Anastasi, A.; Sannia, G.; Varese, G.C. (2008). Decolourisation and detoxification of textile effluents by fungal biosorption. Wat. Res. 42, 2911-2920.

34. Ramsay, J.A.; Nguyen, T. (2002). Decoloration of textile dyes by Trametes versicolor and its effect on dye toxicity. Biotechnol. Lett. 24, $1757-1761$

35. Saparrat, M.C.N.; Hammer, E. (2006). Decolorization of synthetic dyes by the deuteromycete Pestalotiopsis guepinii CLPS no. 786 strain. $J$. Basic Mycrobiol. 46, 28-33.

36. Sharma, P.; Singh, L.; Dilbaghi, N. (2009). Response surface methodological approach for the decolorization of simulated dye effluent using Aspergillus fumigatus fresenius. J. Hazard. Mater. 161, 1081-1086

37. Shedbalkar, U.; Dhanve, R.; Jadhav, J. (2008). Biodegradation of triphenylmethane dye cotton blue by Penicillium ochrochloron MTCC 517 J. Hazard. Mater. 157, 472-479

38. Singh, H. (2006). Mycoremediation: fungal remediation. WileyInterscience, New Jersey.

39. Stemberger, R.S. (1981). A general approach to the culture of planktonic rotifers. Can. J. Fish. Aquat. Sci. 38, 721-724.

40. Tan, N.C.G.; Prenafeta-Boldú, F.X.; Opsteeg, J.L.; Lettinga, G.; Field, J.A. (1999). Biodegradation of azo dyes in cocultures of anaerobic granular sludge with aerobic aromatic amine degrading enrichment cultures. Appl. Microbiol. Biotechnol. 51, 865-871.

41. Ulson de Souza, S.M.A.G.; Forgiarini, E.; Ulson de Souza, A.A. (2007). Toxicity of textile dyes and their degradation by enzyme peroxidase (HRP). J. Hazard. Mater. 147, 1073-1078.

42. Umbuzeiro, G.A.; Roubicek, D. A.; Rech, C. M.; Sato, M. I. Z.; Claxton L. D. (2004). Investigating the sources of the mutagenic activity found in a river using the Salmonella assay and different water extraction procedures. Chemosphere 54, 1589-1597. 
43. Verma, Y. (2008). Toxicity evaluation of effluents from dye and dye intermediate producing industries using Daphnia bioassay. The Internet Journal of Toxicology. http://www.ispub.com/ostia/index.php?xmlPrinter=true\&xmlFilePath=j ournals/ijto/vol4n2/dye.xml

44. Villegas-Navarro, A.; Ramírez-M, Y.; Salvador-S, M.S.; Gallardo, J.M. (2001). Determination of wastewater LC50 of the different process stages of the textile industry. Ecotoxicol. Environ. Saf. 48, 56-61.

45. Yamada-Onodera, K.; Mukumoto, H.; Katsuyaya, Y.; Saiganji, A.; Tani, Y. (2001). Degradation of polyethylene by a fungus, Penicillium simplicissimum YK. Polym. Degrad. Stab. 72, 323-327.

46. Yang, Q.; Yang, M.; Pritsch, K.; Yediler, A.; Hagn, A.; Schloter, M.; Kettrup, A. (2003). Decolorization of synthetic dyes and production of manganese-dependent peroxidase by new fungal isolates. Biotechnol.
Lett. 25, 709-713.

47. Yesilada, O.; Cing, S.; Asma, D. (2002). Decolourisation of the textile dye Astrazon Red FBL by Funalia trogii pellets. Biores. Technol. 81, 155-157.

48. Yu, Z.; Wen, X. (2005). Screening and identification of yeasts for decolorizing synthetic dyes in industrial wastewater. Int. Biodet. Biodegrad. 56, 109-114.

49. Zeng, G.M.; Yu, H.Y.; Huang, H.L.; Huang, D.L.; Chen, Y.N.; Huang, G.H.; Li, J.B. (2006). Laccase activities of a soil fungus Penicillium simplicissimum in relation to liginin degradation. World J. Mycrobiol. Biotechnol. 22, 317-324.

50. Zheng, Z.X; Levin, R.E.; Pinkham, J.L.; Shetty, K. (1999). Decolorization of polymeric dyes by a novel Penicillium isolate. Process Biochem. 34, 31-37. 